\title{
Influence of Physical Characteristics of Flat Aluminum Concentrators on Energy Efficiency of PV/Thermal Collector
}

\author{
LJ. Kostic*, T. Pavlovic and Z. Pavlovic \\ Faculty of Science and Mathematics, Physics Department, University of Nis \\ P.O. Box 224, 18000 Nis, Serbia
}

\begin{abstract}
In this paper the results of the influence of physical characteristics of flat plate solar radiation concentrators made of $\mathrm{Al}$ sheet and $\mathrm{Al}$ foil on energy efficiency of $\mathrm{PV} /$ thermal collector are presented. The measurements results obtained by means of scanning electron microscope, reflectance and chemical composition of solar radiation concentrators are given. Optimal position of solar radiation concentrators and appropriate thermal and electrical energy of $\mathrm{PV} /$ thermal collector were determined. Total generated thermal and electrical energy during the day by $\mathrm{PV} /$ thermal collector with concentrators in optimal position are higher than the total generated thermal and electrical energy obtained by PV/thermal collector without concentrators.
\end{abstract}

PACS numbers: 42.79.Ek, 84.60.Jt

\section{Introduction}

Photovoltaic (PV)/thermal collectors enable better space utilization, savings during supporting construction and simultaneous conversion of solar radiation into thermal and electrical energy in one device. Specially designed PV/thermal collectors can replace outer walls or roof covers. They can be used in private houses, blocks of flats, tourist objects, hospitals, schools and other objects for the heating of sanitary waters and electrical energy generation.

Several theoretical and experimental studies of $\mathrm{PV} /$ thermal systems exist. Among the first, Kern and Russell [1] gave the concept of this system with results, by using of water or air as heat removal fluid. Florschuetz [2] suggests an extension of the Hottel-Whiller model for the analysis of PV/thermal systems. Based on the extended model, examples of both thermal and electrical performance of a combined collector as a function of collector design parameters are presented and discussed. Takashima et al. [3] proposed a PV/thermal collector system consisting of a PV panel placed on a thermal collector, with a gap between them to achieve an effective PV cooling. The energy transfer between the different components of a liquid type PV/thermal collector system with results for electrical and thermal efficiencies was analyzed by Bergene and Lovvik [4]. Various concepts of combined PV/thermal collectors were considered by Zondag et al. [5]. In order to obtain a clearer view on the expected yield of the various concepts, nine different

\footnotetext{
* corresponding author; e-mail: pavlovic@pmf.ni.ac.yu
}

designs were evaluated. In recent years there has been significant progress in fabrication of low bandgap thermophotovoltaic devices [6]. Small thermophotovoltaic systems are also very interesting [7]. The problems of energy performance of $\mathrm{PV} /$ thermal collector systems are also investigated in Refs. [8-12].

$\mathrm{PV} /$ thermal collectors can be combined with low, medium or high concentration devices. The electrical and thermal output of $\mathrm{PV} /$ thermal collector systems can be increased by using concentrators of solar radiation of low concentrating ratio as proposed by Al-Baali [13]. A system consisting of two stages was used: a water circulation system was found to be necessary to overcome the degradation in open circuit voltage $\left(V_{\text {oc }}\right)$ with panel temperature and simultaneously a reflecting mirror was utilized to increase the solar radiation on the panel surface, i.e. to increase short circuit current $\left(I_{\mathrm{sc}}\right)$. An increase in the power output and in hot water can be obtained. Garg et al. [14] study the effect of plane booster reflectors on the performance of a solar air heater with solar cells suitable for a solar dryer. Brogren et al. [15] gave results from a water-cooled $\mathrm{PV} /$ thermal system with $4 \mathrm{X} \mathrm{CPC}$ reflectors that presents yearly electric output increase by $20 \%$.

Tripanagnostopoulos et al. [16] presented test results on hybrid solar systems. They described hybrid $\mathrm{PV} /$ thermal experimental models based on commercial PV modules of typical size and presented test results of the systems. The results showed that PV cooling can increase the electrical efficiency of PV modules, increasing the total efficiency of the systems. Improvement of the system performance can be achieved by the use of an additional glazing to increase thermal output, a booster diffuse reflector to increase electrical and thermal output, 
or both, giving flexibility in system design.

Tripanagnostopoulos et al. [17] studied water-cooled $\mathrm{PV} /$ thermal solar systems. They determined the electrical and thermal efficiency and the annual energy output under the weather conditions of Patras in Greece for horizontal and tilted building roof installation. The costs of all system parts are included and the cost payback time is estimated. Also the methodology of life cycle assessment (LCA) has been applied to perform an energy and environmental assessment of the analyzed system. The most important conclusion is that $\mathrm{PV} /$ thermal collector systems are cost effective and of better environmental impact compared with standard PV modules. A new type of $\mathrm{PV} /$ thermal collector with dual heat extraction operation, either with water or with air circulation was presented by Tripanagnostopoulos [18]. The modified dual $\mathrm{PV} /$ thermal collectors were combined with booster diffuse reflectors, achieving a significant increase in system thermal and electrical energy output.

In the present paper the influence of morphology, reflectance and position of flat plate solar radiation concentrators made of $\mathrm{Al}$ sheet and $\mathrm{Al}$ foil on energy efficiency of $\mathrm{PV} /$ thermal collector are analyzed.

\section{Experiment}

The experiment has been conducted in Solar Energy Laboratory of the Faculty of Science and Mathematics in Nis from June till August 2008. Measurements have been performed on $\mathrm{PV} /$ thermal collector with and without flat plate solar radiation concentrators.

$\mathrm{PV} /$ thermal collector, dimensions $1.37 \times 0.72 \mathrm{~m}^{2}$ and the surface $0.986 \mathrm{~m}^{2}$, is made of electrolytically colored anodized aluminum box, thermal insulation from mineral wool, PV/thermal absorber, $\mathrm{Al}$ sheet on the back and protective glass on the front side.

$\mathrm{PV} /$ thermal absorber is composed of interconnected $\mathrm{Al}$ sheets with copper tubes installed in the bottom and solar module with solar cells made of monocrystal silicon which is mechanically fixed to $\mathrm{Al}$ sheets. Power of solar module at temperature $T=25^{\circ} \mathrm{C}$ and the solar radiation intensity of $I=1000 \mathrm{~W} / \mathrm{m}^{2}$ is $110 \mathrm{~W}$, and voltage is $12 \mathrm{~V}$. Concentrators are made of $\mathrm{Al}$ sheet and $\mathrm{Al}$ foil, respectively, of dimensions of $1.37 \times 0.72 \mathrm{~m}^{2}$.

Schematic diagram of the $\mathrm{PV} /$ thermal collector with solar radiation concentrators is shown in Fig. 1.

$\mathrm{PV} /$ thermal collector is mounted on the metal support made of bottom (fixed) and upper (movable) part thus enabling tilting of the collector in relation to the horizontal plane of $0-90^{\circ}$. $\mathrm{PV} /$ thermal collector in this experiment has been in a position angle of $45^{\circ}$ in relation to the horizontal plane and has been south oriented.

Two concentrators have been mounted on PV/thermal collector with the changeable position in relation to $\mathrm{PV} /$ thermal collector. In order to obtain the highest solar radiation intensity on $\mathrm{PV} /$ thermal collector, a position of the bottom and upper concentrator has been changed.

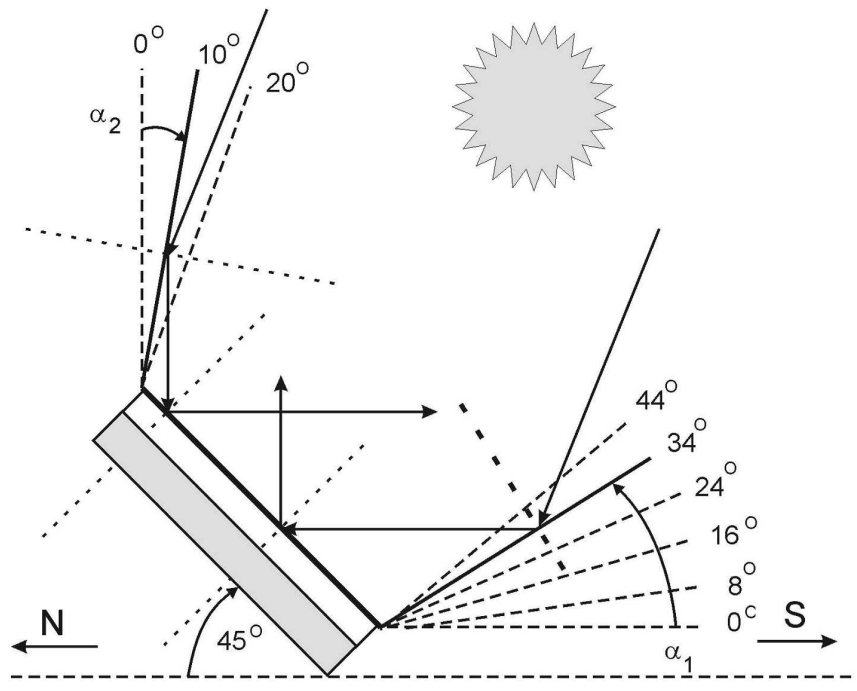

Fig. 1. Schematic diagram of the PV/thermal collector with solar radiation concentrators.

\subsection{Measuring equipment}

For investigation of surface of $\mathrm{Al}$ sheet and $\mathrm{Al}$ foil scanning electron microscope (SEM) JEOL JSM-5300 has been used.

For the determination of chemical composition optical emission spectrometer DFS-8 has been used.

For the measurement of total and diffuse reflectance from Al sheet and Al foil Beckman UV/VIS/NIR 5240 Spectrophotometer with integrating sphere has been used.

For the determination of thermal and electrical characteristics of $\mathrm{PV} /$ thermal collector the system, schematically given in Fig. 2, has been used.

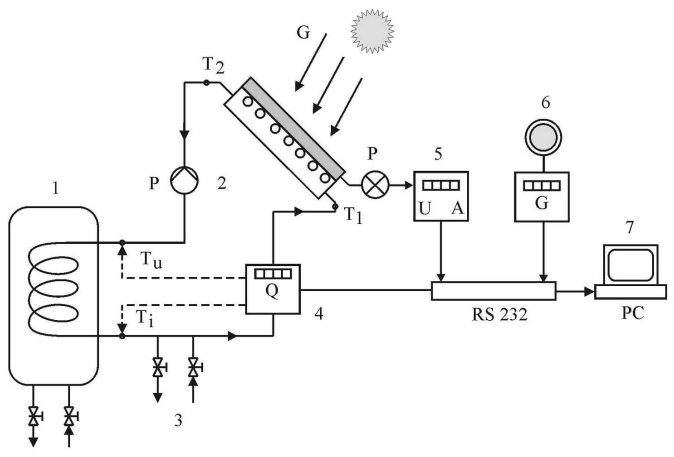

Fig. 2. Schematic diagram of the system for the determination of thermal and electrical characteristics of PV/thermal collector: (1) hot water storage, (2) pump, (3) valves, (4) calorimeter Multical 401, (5) AD converter, (6) pyranometer, (7) computer.

For the measurement of incoming and output temperature from the collector and water temperature in hot water storage electrical thermometers with Pt-100 temperature sensors have been used. 
For the measurement of the obtained thermal energy in hot water storage and the water mass flow rate Multical 401 calorimeter has been used.

For the measurement of electrical characteristics of $\mathrm{PV} /$ thermal collector electronic device for the acquisition of data VT-08 NIGOS has been used.

For the measurement of solar radiation intensity and incident concentrated solar radiation on $\mathrm{PV} /$ thermal collector MINI-KLA device has been used. This device has a sensor which is monocrystalline silicon solar cell.

For the measurement of meteorological parameters: the ambient temperature $T_{\mathrm{a}}$ and the wind speed $V_{\mathrm{w}}$, automatic meteorological station Vantage PRO DAVIS has been used.

\subsection{Measuring methods}

Heated water is brought to the hot water storage by means of circulation pump. Each morning hot water from the hot water storage was drained and storage was again filled with cold water. Heating of water in hot water storage during the day was continuously monitored in the period from 8 till 17.00 hours. At the end of the day water temperature in hot water storage was measured.

Generated electrical energy is through battery charge regulator transmitted to the battery and then directly through $\mathrm{DC} / \mathrm{AC}$ inverter submitted to the consumer. VT-08 NIGOS measures change in the current and voltage in $\mathrm{PV} /$ thermal collector during the day. This device is analog-digital converter with microcontroller which enables digital measurement of voltage, currency, temperature etc. It is connected with the computer by RS-232 and can be software programmed. Measured current values of voltage, currency and power are recorded in table form in a file on PC and are graphically shown on the monitor which is suitable for data analysis. Current and voltage in $\mathrm{PV} /$ thermal collector were measured every $10 \mathrm{~min}$ and registered in the form of tables and graphics by computer. On the basis of these values total of generated electrical energy has been determined.

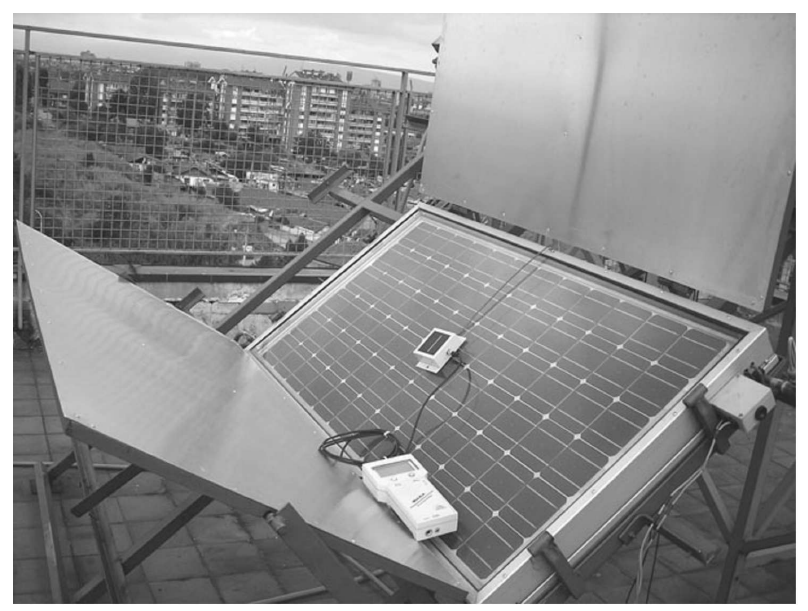

Fig. 3. Measurements of concentrated solar radiation by MINI-KLA device.
Measurements of solar radiation intensity were performed during an hour with solar cell in the middle of PV/thermal collector (Fig. 3).

All meteorological data were registered in $10 \mathrm{~min}$ intervals and were given in graphic and table form.

\subsection{Calculating methods}

The concentration factor $(C)$ of solar radiation intensity is calculated by relation

$$
C=\frac{G_{\text {tot }}}{G_{\text {net }}},
$$

where $G_{\text {net }}$ is net incoming solar radiation intensity and $G_{\text {tot }}$ is total solar radiation intensity.

The total solar radiation intensity is determined by relation

$$
G_{\text {tot }}=G_{\text {net }}+G_{\text {ref }},
$$

where $G_{\text {ref }}$ is reflected solar radiation intensity from concentrators which reached to collector surface.

Total daily thermal performance $\eta_{\mathrm{T}}$ is calculated by relation

$$
\eta_{\mathrm{T}}=\frac{E_{\mathrm{T}}}{E_{\mathrm{S}}},
$$

where $E_{\mathrm{T}}$ is the total generated thermal energy during the day by $\mathrm{PV} /$ thermal collector (Wh) and $E_{\mathrm{S}}$ is the total incoming solar radiation energy during the day (Wh) on $\mathrm{PV} /$ thermal collector without concentrators.

Total daily electrical performance $\eta_{\mathrm{E}}$ is calculated by relation

$$
\eta_{E}=\frac{E_{\mathrm{E}}}{E_{\mathrm{S}}},
$$

where $E_{\mathrm{E}}$ is the total generated electrical energy during the day by $\mathrm{PV} /$ thermal collector (Wh) and $E_{\mathrm{S}}$ is the total incoming solar radiation energy during the day (Wh) on $\mathrm{PV} /$ thermal collector without concentrators.

Thermal performance of $\mathrm{PV} /$ thermal system with concentrators depend on the water input temperature $\left(T_{\mathrm{i}}\right)$, ambient temperature $\left(T_{\mathrm{a}}\right)$, incident net solar radiation intensity $\left(G_{\text {net }}\right)$ and the concentration factor $(C)$.

\section{Results and discussion}

SEM photos of $\mathrm{Al}$ sheet and $\mathrm{Al}$ foil surfaces are given in Fig. 4 and Fig. 5. In the figures can be seen that $\mathrm{Al}$ sheet and $\mathrm{Al}$ foil surfaces have similar structure with certain degree of microroughness.

Chemical composition of $\mathrm{Al}$ sheet is $\mathrm{Al}$ (99.99\%) and Fe $(0.01 \%)$.

Total, diffuse and specular reflectance from the flat solar radiation concentrator made of $\mathrm{Al}$ sheet and $\mathrm{Al}$ foil in the visible region are given in Fig. 6 and Fig. 7 .

In Figs. 6 and 7 can be seen that the total reflectance from $\mathrm{Al}$ sheet and $\mathrm{Al}$ foil is almost the same, that the diffuse reflectance from $\mathrm{Al}$ sheet is higher than diffuse reflectance from $\mathrm{Al}$ foil and that specular reflectance from $\mathrm{Al}$ sheet is lower than specular reflectance from $\mathrm{Al}$ foil.

A change of concentrated solar radiation intensity $(G)$ measured during the sun peak (13 August 2008) and depending on the position of the concentrator made of $\mathrm{Al}$ 


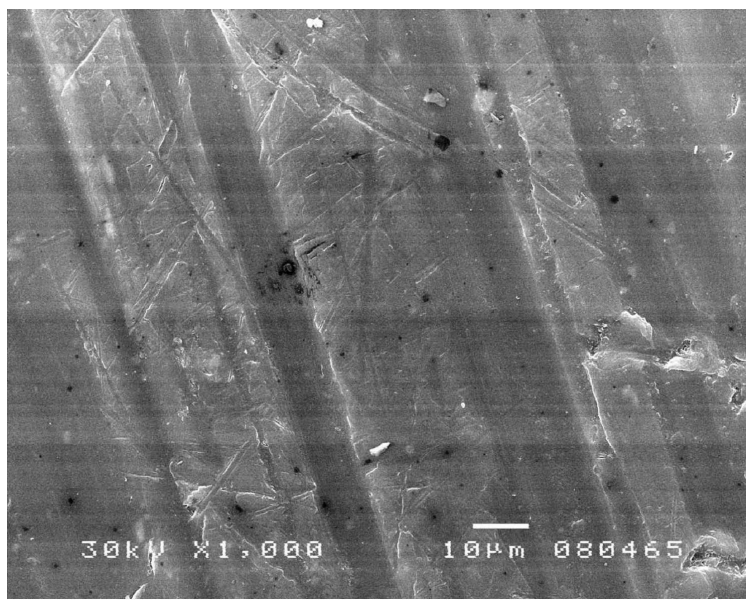

Fig. 4. SEM photo of $\mathrm{Al}$ sheet surface.

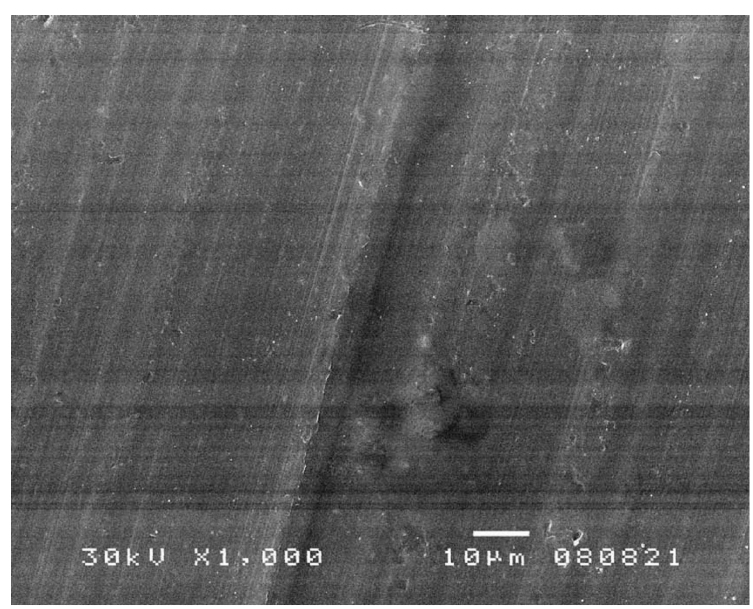

Fig. 5. SEM photo of $\mathrm{Al}$ foil surface.

sheet and $\mathrm{Al}$ foil is given in Fig. 8 and Fig. 9. In figures $\alpha_{1}$ means angle between bottom concentrator and horizontal plane and $\alpha_{2}$ means angle between upper concentrator and vertical plane.

Based on the measurement results for concentrated solar radiation intensity during the day for different positions of the concentrators in relation to $\mathrm{PV} /$ thermal collector an optimal position of concentrator was determined whereby a concentration factor $(C)$ of solar radiation intensity is maximal one. This is the position where the upper concentrator is under angle of $10^{\circ}$ in relation to the vertical plane and bottom concentrator is under angle of $34^{\circ}$ in relation to the horizontal plane.

Concentrated solar radiation intensity for $\mathrm{PV} /$ thermal collector with concentrators made of $\mathrm{Al}$ foil is higher than concentrated solar radiation intensity for $\mathrm{PV} /$ thermal collector with concentrators made of $\mathrm{Al}$ sheet for all positions of concentrators.

A change in solar radiation intensity in $\mathrm{PV} /$ thermal collector with and without concentrator made of $\mathrm{Al}$ sheet during the day for the optimal position on concentrator is

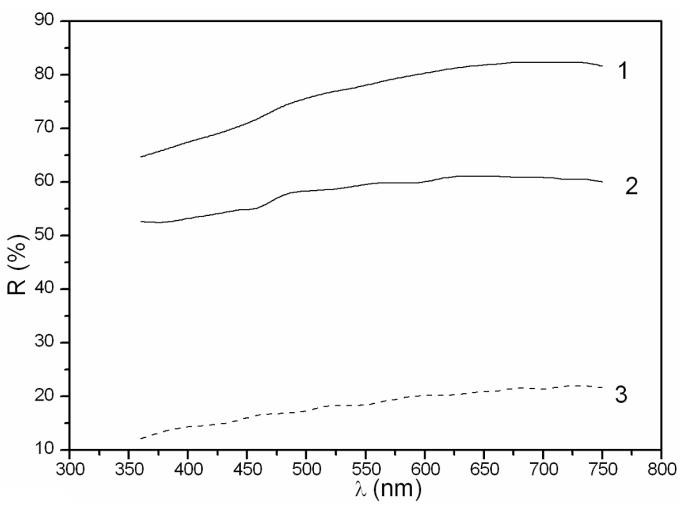

Fig. 6. Reflectance from Al sheet: (1) total, (2) diffuse, (3) specular.

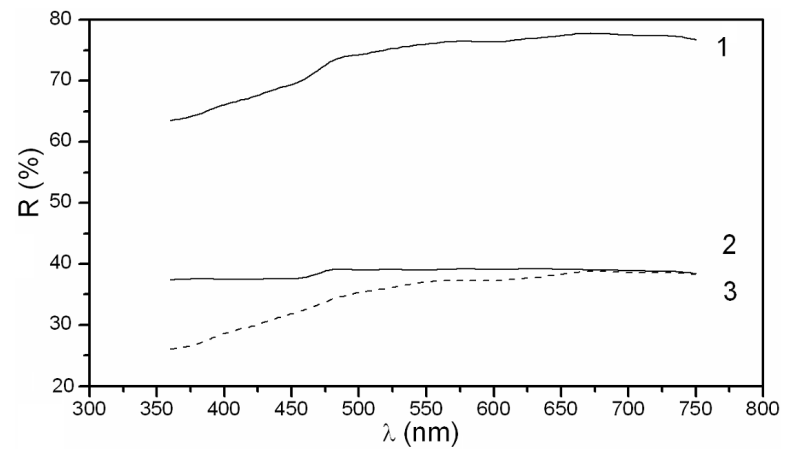

Fig. 7. Reflectance from Al foil: (1) total, (2) diffuse, (3) specular.

shown in Fig. 10 (19 August 2008). Relative increase in solar radiation intensity generated by $\mathrm{PV} /$ thermal collector with concentrators made of $\mathrm{Al}$ sheet in optimal position in relation to $\mathrm{PV} /$ thermal collector without concentrator for this day is $43.6 \%$.

A change in solar radiation intensity in $\mathrm{PV} /$ thermal collector with and without concentrators made of $\mathrm{Al}$ foil during the day for the optimal position on concentrator is shown in Fig. 11 (21 August 2008). Relative increase in solar radiation intensity generated by $\mathrm{PV} /$ thermal collec-

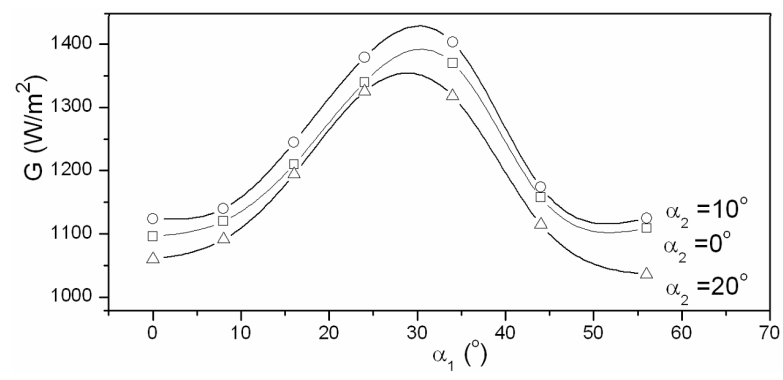

Fig. 8. A change of concentrated solar radiation intensity depending on concentrator position for concentrator made of $\mathrm{Al}$ sheet. 


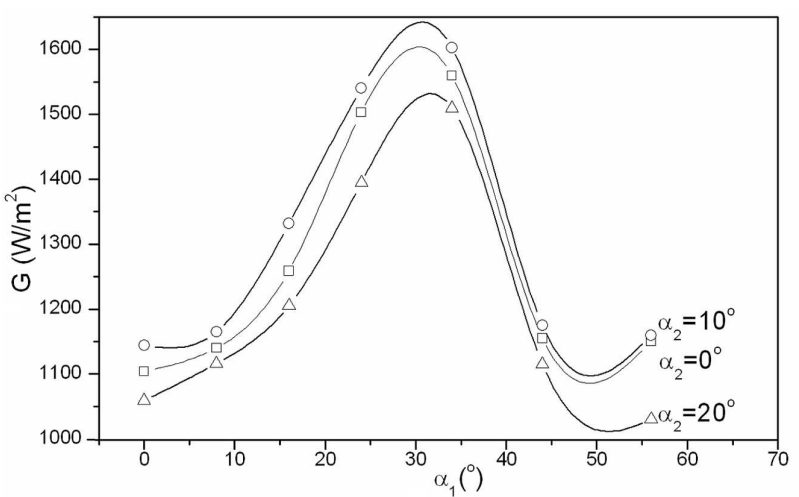

Fig. 9. A change of concentrated solar radiation intensity depending on concentrator position for concentrator made of $\mathrm{Al}$ foil.

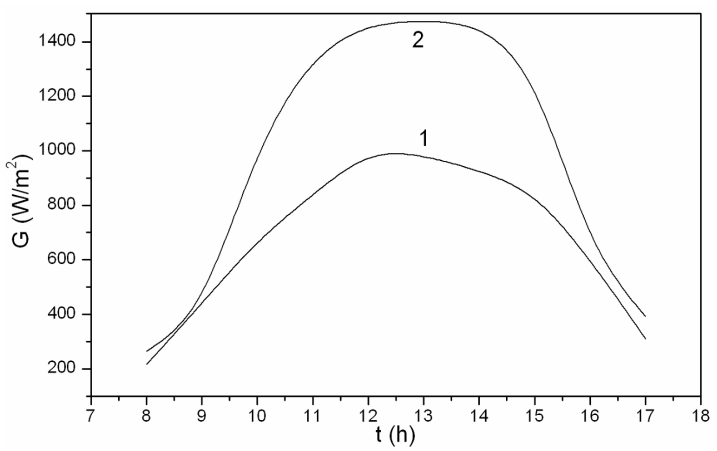

Fig. 10. A change in concentrated solar radiation intensity in $\mathrm{PV} /$ thermal collector during the day: (1) without concentrator, (2) with concentrators made of $\mathrm{Al}$ sheet.

tor with concentrators made of $\mathrm{Al}$ foil in optimal position in relation to $\mathrm{PV} /$ thermal collector without concentrator for this day is $65.6 \%$.

Changes of the total generated thermal energy during the day by $\mathrm{PV} /$ thermal collector with concentrators in

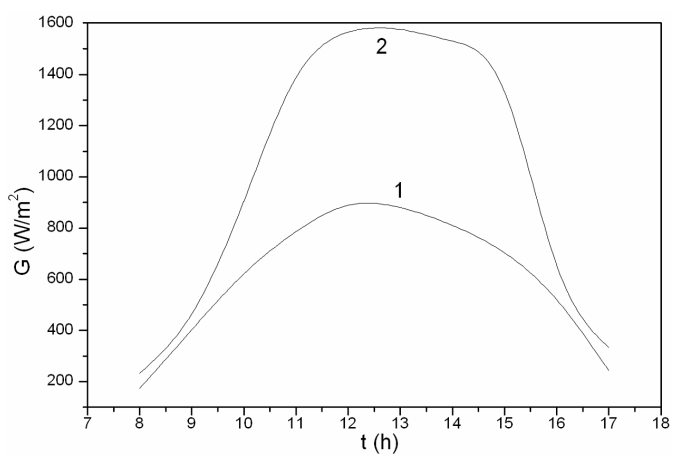

Fig. 11. A change in concentrated solar radiation intensity in $\mathrm{PV} /$ thermal collector during the day: (1) without concentrator, (2) with concentrators made of $\mathrm{Al}$ foil.

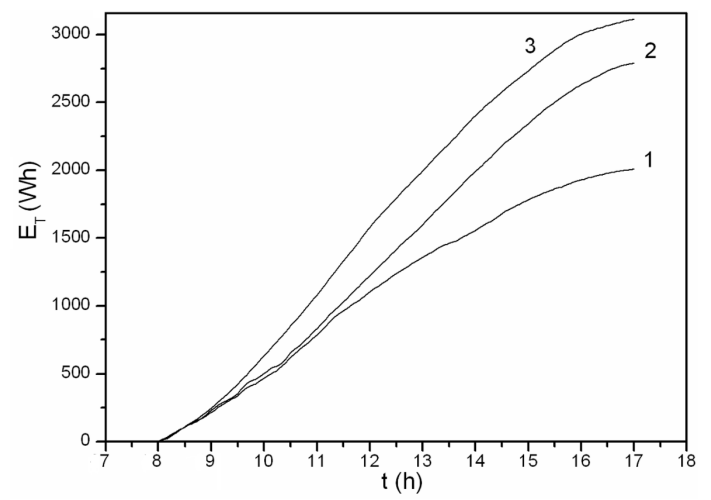

Fig. 12. Changes of the total generated thermal energy during the day by PV/thermal collector: (1) without concentrator, (2) with concentrators made of $\mathrm{Al}$ sheet, (3) with concentrators made of $\mathrm{Al}$ foil.

optimal position and without concentrator are shown in Fig. 12.

Measurements during the day have shown that by increase in the solar radiation intensity by $43.6 \%$ in $\mathrm{PV} /$ thermal collector with concentrators made of $\mathrm{Al}$ sheet compared to $\mathrm{PV} /$ thermal collector without concentrator total generated thermal energy has increased by $39 \%$, and that by increase in the solar radiation intensity by $65.6 \%$ in $\mathrm{PV} /$ thermal collector with concentrators made of $\mathrm{Al}$ foil compared to $\mathrm{PV} /$ thermal collector without concentrator total generated thermal energy has increased by $55 \%$ which is shown in Fig. 13.

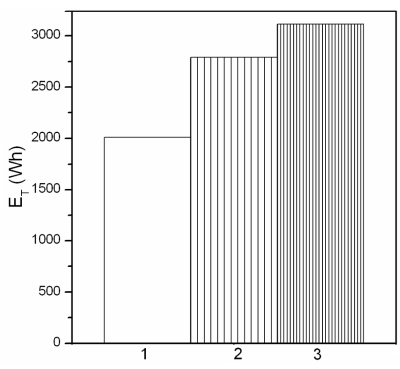

Fig. 13. Total daily thermal energy generated by PV/thermal collector: (1) without concentrator, (2) with concentrators made of $\mathrm{Al}$ sheet, (3) with concentrators made of $\mathrm{Al}$ foil.

Total daily thermal performance $\eta_{\mathrm{T}}$ is increasing with the solar radiation intensity concentration factor. The value of the total daily thermal performance $\eta_{\mathrm{T}}$ is $33 \%$ for $\mathrm{PV} /$ thermal collector without concentrator, $42 \%$ for $\mathrm{PV} /$ thermal collector with concentrators made of $\mathrm{Al}$ sheet and $52 \%$ for PV/thermal collector with concentrators made of Al foil.

Changes of the total generated electrical energy during the day by $\mathrm{PV} /$ thermal collector with concentrator in optimal position and without concentrator are shown in Fig. 14 . 


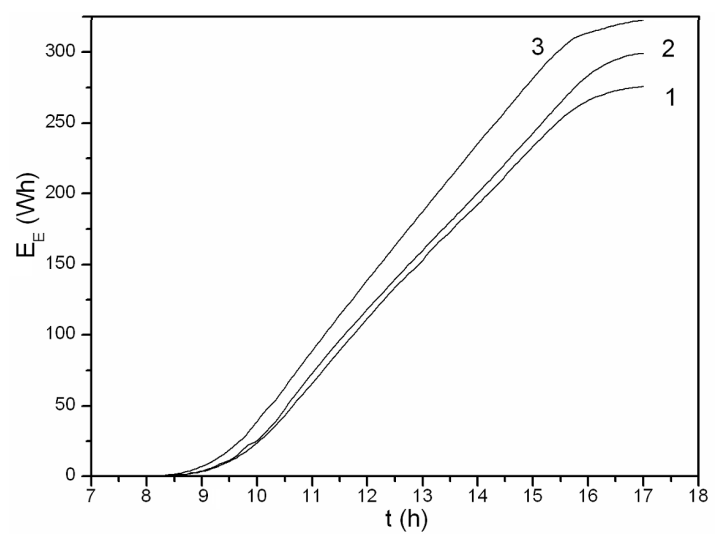

Fig. 14. Changes of the total generated electrical energy during the day by PV/thermal collector: (1) without concentrator, (2) with concentrators made of $\mathrm{Al}$ sheet, (3) with concentrators made of $\mathrm{Al}$ foil.

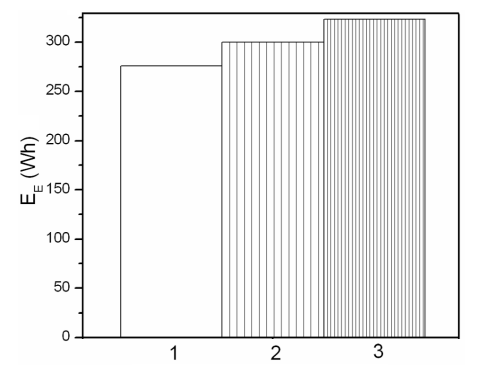

Fig. 15. Total daily electrical energy generated by PV/thermal collector: (1) without concentrator, (2) with concentrator made of $\mathrm{Al}$ sheet, (3) with concentrators made of $\mathrm{Al}$ foil.

Measurements during the day have shown that by increase in the solar radiation intensity by $43.6 \%$ in $\mathrm{PV} /$ thermal collector with concentrators made of $\mathrm{Al}$ sheet compared to $\mathrm{PV} /$ thermal collector without concentrator total generated electrical energy has increased by $8.6 \%$, and that by increase in the solar radiation intensity by $65.6 \%$ in $\mathrm{PV} /$ thermal collector with concentrators made of $\mathrm{Al}$ foil compared to $\mathrm{PV} /$ thermal collector without concentrator total generated electrical energy has increased by $17.1 \%$ which is shown in Fig. 15 .

Total daily electrical performance $\eta_{\mathrm{E}}$ increases slightly with the solar radiation intensity concentration factor. The value of the total daily electrical performance $\eta_{\mathrm{E}}$ is $4.5 \%$ for $\mathrm{PV} /$ thermal collector without concentrator, $4.8 \%$ for $\mathrm{PV} /$ thermal collector with concentrators made of $\mathrm{Al}$ sheet and $5.2 \%$ for $\mathrm{PV} /$ thermal collector with concentrators made of $\mathrm{Al}$ foil.

\section{Conclusion}

Based on the above mentioned one can conclude the following:

1. The total, diffuse and specular reflectance from flat solar radiation concentrators made of $\mathrm{Al}$ sheet in the visible region is $65-82 \%, 52-61 \%$ and $13-21 \%$, respectively.

2. The total, diffuse and specular reflectance from flat solar radiation concentrators made of $\mathrm{Al}$ foil in the visible region is $64-78 \%, 37-39 \%$ and $27-39 \%$, respectively.

3. Optimal position of the concentrator is for $\alpha_{1}=34^{\circ}$ in relation to the horizontal plane and $\alpha_{2}=10^{\circ}$ in relation to the vertical plane.

4. In optimal position of concentrator the daily concentration factor of solar radiation intensity is $43.6 \%$ for concentrator made of $\mathrm{Al}$ sheet and $65.6 \%$ for concentrator made of $\mathrm{Al}$ foil.

5. Total daily thermal energy generated by $\mathrm{PV} /$ thermal collector with concentrators made of $\mathrm{Al}$ sheet in optimal position is by $39 \%$ higher than the total generated thermal energy obtained by $\mathrm{PV} /$ thermal collector without concentrator.

6. Total daily thermal energy generated by $\mathrm{PV} /$ thermal collector with concentrators made of Al foil in optimal position is by $55 \%$ higher than the total generated thermal energy obtained by $\mathrm{PV} /$ thermal collector without concentrator.

7. Total daily electrical energy generated by $\mathrm{PV} /$ thermal collector with concentrators made of $\mathrm{Al}$ sheet in optimal position is by $8.6 \%$ higher than the total generated thermal energy obtained by $\mathrm{PV} /$ thermal collector without concentrator.

8. Total daily electrical energy generated by $\mathrm{PV} /$ thermal collector with concentrators made of $\mathrm{Al}$ foil in optimal position is by $17.1 \%$ higher than the total generated thermal energy obtained by $\mathrm{PV} /$ thermal collector without concentrator.

9. Total daily thermal performance $\eta_{\mathrm{T}}$ increases with the solar radiation intensity concentration factor.

10. Total daily electrical performance $\eta_{\mathrm{E}}$ increases slightly with the solar radiation intensity concentration factor.

\section{Acknowledgments}

The authors gratefully acknowledge the financial support from Ministry of Science of the Republic of Serbia through project No. 273009.

\section{References}

[1] E.C. Kern Jr., M.C. Russell, in: Proc. 13th IEEE Photovoltaic Specialists, Washington DC 1978, IEEE, New York 1978, p. 1153.

[2] L.W. Florschuetz, Solar Energy 22, 361 (1979). 
[3] T. Takashima, T. Tanaka, T. Doi, J. Kamoshida, T. Tani, T. Horigome, Solar Energy 52, 241 (1994).

[4] T. Bergene, O.M. Lovvik, Solar Energy 55, 453 (1995).

[5] H.A. Zondag, D.W. De Vries, W.G.J. Van Helden, R.J.C. Van Zolingen, A.A. Van Steenhoven, Solar Energy 74, 253 (2003).

[6] K. Qiu, A.C.S. Hayden, Solar Energy 74, 489 (2003).

[7] W. Durisch, B. Bitnar, F. von Roth, G. Palfinger, Solar Energy 75, 11 (2003).

[8] Y.B. Assoa, C. Menezo, G. Fraisse, R. Yezou, J. Brau, Solar Energy 81, 1132 (2007).

[9] G. Fraisse, C. Menezo, K. Johannes, Solar Energy 81, 1426 (2007).

[10] J.K. Tonui, Y. Tripanagnostopoulos, Solar Energy 81, 498 (2007).

[11] J.K. Tonui, Y. Tripanagnostopoulos, Solar Energy 82, 1 (2008).
[12] S. Dubey, G.N. Tiwari, Solar Energy 82, 602 (2008).

[13] A.A. Al-Baali, Solar Wind Technol. 3, 241 (1986).

[14] H.P. Garg, R.K. Agarwal, A.K. Bhargava, Energy Conv. Manag. 32, 543 (1991).

[15] M. Brogren, M. Ronnelid, B. Karlson, in: Proc. 16th European PV Solar Energy Conf., Glasgow 2000, Eds. James \& James, Vol. III, Earthscan, London 2001, p. 2121.

[16] Y. Tripanagnostopoulos, Th. Nousia, M. Souliotis, P. Yianoulis, Solar Energy 72, 217 (2002).

[17] Y. Tripanagnostopoulos, M. Souliotis, R. Battisti, A. Corrado, Prog. Photovolt. Res. Appl. 13, 235 (2005).

[18] Y. Tripanagnostopoulos, Solar Energy 81, 1117 (2007) 